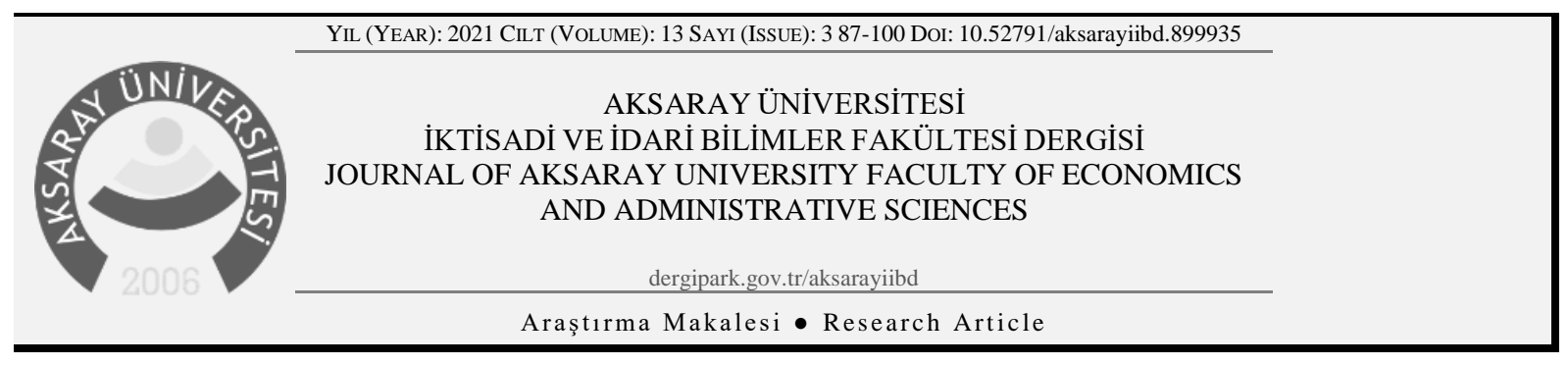

\title{
Tersine Lojistiğin Bibliyometrik Analizi
}

\section{A Bibliometric Analysis of Reverse Logistics}

\author{
Mahmut Tekin ${ }^{1}$, Derya Ö̈türk ${ }^{2}$ ve Ísmail Bahar ${ }^{3}$ \\ ${ }^{1}$ Prof. Dr., Selçuk Üniversitesi, İktisadi ve İdari Bilimler Fakültesi, İşletme Bölümü, mahtekin@selcuk.edu.tr, Orcid ID: 0000-0003-0558- \\ 4271 \\ ${ }^{2}$ Doç. Dr., Ordu Üniversitesi, Ünye İktisadi ve İdari Bilimler Fakültesi, İsletme Bölümü, deryaozturk@odu.edu.tr, Orcid ID: 0000-0001-5287- \\ 6600 \\ ${ }^{3}$ Doktora Öğrencisi, Selçuk Üniversitesi, Sosyal Bilimler Enstitüsü, ismailbahar@yandex.com, Orcid ID: 0000-0002-8199-4865
}

M A K A LE B İLGİS İ

Anahtar Kelimeler

Tersine Lojistik,

Sürdürülebilirlik,

Bibliyometrik Analiz,

Vosviewer,

Web of Science
Makale Geçmişi:

Geliş Tarihi: 19 Mart 2021

Kabul Tarihi: 16 Ağustos 2021

\section{ARTICLEINFO}

\section{Keywords}

Reverse Logistics,

Sustainability,

Bibliometric Analysis,

VOSviewer,

Web of Science

\section{Article History:}

Received: 19 March 2021

Accepted: 16 August 2021

\section{Ö ZET}

Küresel bir dünyada üretim ve pazarlama zincirinde lojistik faaliyetleri, uluslararası bir ağ oluşturularak karmaşık süreçlere göre yapılmaktadır. Lojistik süreçleri artan sürdürülebilirlik gereksinimi ve artan çevresel kirlilik sonucunda; ürünlerin ve çeşitli malzemelerin geri dönüşümü ile atıkların imhası işlemleriyle birlikte tersine lojistiğe dönüşmüştür. Bu çalışmanın amacı, tersine lojistik ile ilgili olarak 2016-2020 yılları arasında yapılan araştırmaların yoğunlaştı̆ı konular, coğrafya ve araştırmacılar belirlenerek tersine lojistikle ilgili literatüre bibliyometrik analiz katkısıyla yol gösterici olabilmektir. Bu amaçla Web of Science (WOS) veri tabanından alınan tersine lojistikle ilgili 182 makale bibliyometrik analiz yöntemi ile incelenmiştir. Araştırmada bibliyometrik analiz yöntemi için geliştirilen VOSviewer adlı paket programı kullanılmıştır. Yapılan analizler sonucunda tersine lojistik alanında yapılan yayınlarda en yüksek atıf sayısının 2019 yılında gerçekleştiği, en sık kullanılan anahtar kelimenin sürdürülebilirlik (sustainability) olduğu belirlenmiştir. Ayrıca en fazla çalışma yapan ülkenin Çin Halk Cumhuriyeti, en fazla atıf puanına sahip olan ülkenin Danimarka olduğu tespit edilmiştir. Analiz bulgularına göre, Kannan Govindan'ın bu alanda en fazla yayın yapan ve atıf alan araştırmacı olduğu sonucuna ulaşı1mıştır.

\begin{abstract}
A B S T R A C T
Logistics activities in the manufacture and marketing chain in a global world are conducted in line with complex processes by generating an international network. As a result of the increasing environmental pollution and the need for sustainability, logistics processes have turned into reverse logistics with waste disposal and recycling of products and materials. The aim of this study is to screen articles on reverse logistics between 2016 and 2020 and identify the topics, geographies, and researchers they focus on in order to shed light on the topic through bibliometric analysis and contribute to the literature and pave the way for further research. For this purpose, the Web of Science (WOS) database has been scanned. The review yielded 182 articles on reverse logistics, which were analyzed through bibliometric analysis conducted using VOSviewer software package. The results showed that articles on reverse logistics were most cited in 2019 and that the most frequently used keyword was sustainability. Most studies were from the People's Republic of China. Denmark has the highest citation score. According to the analysis results, Kannan Govindan is the researcher who has published the most articles and been cited the most by other researchers.
\end{abstract} çamaşır makinesi ve televizyon gibi eşyalar lojistik süreçlerine bağlı işlemler sonucunda müşterilere ulaşmaktadır. Bir bakıma lojistik müşterilerin hayatının hemen her yerini kuşatan, yaşamlarını sürdürebilmeleri için gerekli olan temel faaliyetlerden birisidir (Tekin, 2015:3). Küresel dijital ekonomide lojistik süreçlerle birbirine bağlı işlemler dizisini oluşturan; 
tedarik, satın alma, ihale ve pazarlık yöntemleri ve rekabetçi süreçlerin yönetimi gibi karmaşık işlemler tedarik zinciri ağıyla yapılmaktadır (Tekin, 2018:64).

Tedarik zincirinin alt unsuru olarak değerlendirilen lojistik, bağımsız bir disiplin olarak hızla gelişmektedir. İlk olarak askeri alanda kullanılan lojistik kavramı, dünya tarihinindeki büyük savaşların sonucunu değiştirecek kadar etkili olmuştur. 1900'lü yıllardan 1960'lı yıllara kadar gelen dönemde lojistik, firmalarca rekabet avantajı yaratan bir alan olmaktan ziyade sadece operasyonel bir fonksiyon olarak görülmekteydi. 1960’lı yıllarda lojistik faaliyetlerinin farklı departmanlara dağıtılmasının, maliyet kayıplarına yol açtığı düşüncesiyle etkin olmadığı anlaşılmaya başlanmıştır (Öztürk, 2016:18). Lojistiğin tarihsel gelişim süreci incelendiğinde işletmecilik bağlamında bugünkü manada bu kavramın öneminin 1970’li yıllara kadar farkına varılmamıştır. Sonraki yıllarda özellikle kitlesel üretimin artmasıyla birlikte üretim için gerekli olan çok sayıda ve büyük miktarda girdilerin ve üretim süreci sonucunda üretilen ürünlerin dağıtım işlemleri için lojistik faaliyetlerine ihtiyaç duyulmuştur (Tekin, 2015:3). İşletme biliminde lojistik faaliyetleri, fabrikaların hammadde tedarik sağlayıcılarından başlayarak son kullanıcı olan nihai tüketiciye ulaşması ile devam eden, genellikle ileri yönlü faaliyetler dizisidir. Bu bağlamda lojistik, üretimden (üreticiden-fabrikadan) pazarlamaya (tüketiciye-pazara) doğru bir yön izlemektedir. Bazen ise değişen koşullara bağlı olarak tersine lojistik olarak pazardan üretime doğru yapılan geri yönlü bir faaliyettir.

Dünya ekonomisinde küreselleşmeyle birlikte üretilen malların tedarik ve taşıma süreci büyük bir önem kazanmıştır. Bu bağlamda küresel üreticiler tüm üretim ve dağıtım süreçlerini lojistik odaklı olarak tasarlamak durumunda kalmışlardır. Tedarik zincirine bağlı olarak lojistik süreçleri ve işlemleri iş süreçleriyle bütünleştirilerek onların tamamlayıcısı durumuna gelmiştir. Tüketicilerin günlük hayatında yer alan yemek, sinema ve taksi işlemleriyle ilgili rezervasyon, çağırma ve ödeme işlemleri akıllı telefon uygulamaları ile birlikte lojistik süreçleriyle onların hayatını kolaylaştırmaktadır. Örneğin; Alibaba.com işletmesi Çin'deki bölgesel lojistik şirketleriyle ortaklığa giderek ürünlerin ve hizmetlerin sunumunda önemli lojistik avantajlarını kullanarak Google harita uygulamalarına benzeyen bir uygulama sonucu harita kolaylığı ile müşterilere hızlı ve etkin ulaşım sunmaya çalışmaktadır (Tekin, 2019:40). Buchman 2018 raporuna göre; Amazon'un dünya çapında 486 adet dağıtım noktası, binlerce kamyonu bulunmakta ve 32 adet Boeing 767 uçağını lojistik bekleme süreçlerini en iyi şekilde yönetmek üzere kullanmaktadır (Buchman, 2018). Amazon ve Alibaba markalarının en önemli özelliği lojistik alt yapılarının rakiplerinden daha iyi durumda olarak lojistik süreçlerini en iyi şekilde yönetmeleridir (Tekin vd., 2020:571).

Sanayi devrimiyle birlikte üretimdeki hızlı artış ve özellikle son yıllarda teknolojideki olağanüstü gelişmeler sonucunda yoğun kitlesel üretimle birlikte ortaya çıkan üretim fazlalığı pazarlarda önemli değişime yol açmıştır. Bu değişimle birlikte tüketicinin daha değerli, daha özgür ve daha seçici olmasıyla tüketici algıları ve beklentileri de hızla çeşitlenerek değişime uğramıştır. Bu duruma bağlı olarak fazla üretilerek pazara sunulan malların tekrar toplanması ve depolanması tersine lojistik faaliyetlerine neden olmuştur. Ayrıca tüketiciler tarafından kullanılarak geri dönüşümle ekonomiye kazandırılacak ürünlerin tekrar üretilmek üzere fabrikalara gelmesi; lojistiğin, tüketiciden üreticiye doğru geri yönlü yapılmasına sebep olmuştur. Sınırsız olan insan ihtiyaçlarının kıt kaynaklarla karşılanması sadece doğal kaynağı verimli kullanmakla mümkün değildir. Kullanılan ürünlerin geri kazanımı veya korunması, paketlenmesi gibi faaliyetlerde kullanılan malzemelerin geri kazanımı da önemlidir. Bu atıkların geri dönüşüm için toplanmasında sadece işletmelerin duyarlılığ yeterli olmamaktadır. Geri dönüşümle kullanılan ürünlerin ekonomiye kazandırılmasında işletmelerle birlikte tüketicilerin de duyarlı olması daha etkili sonuçların alınması bakımından faydalı olmaktadır. İşletmelerin ve tüketicilerin farkındalığının artmasıyla birlikte tersine lojistik faaliyetleri her geçen gün daha da önem kazanmaktadır. Bu faaliyetler yapılırken müşteri memnuniyeti, hız ve maliyet gibi birçok etki işletmelerin tersine lojistik faaliyetlerine yoğunlaşmasına sebep olmuştur. Günümüzde tedarik zincirinin önemli süreçlerinden birisi olan tersine lojistik idari, ekonomik ve yasal zorunluluk haline gelmektedir. Tersine lojistiğin önemi ve etkisi sektörden sektöre ve işletmenin dağıtım kanalındaki yerine göre değişmektedir. Otomobil sektörü gibi ürünün değerinin fazla olduğu ya da geri dönüşüm oranının yüksek olduğu sektörlerdeki tersine lojistik faaliyetleri oldukça büyük bir öneme sahiptir. Tersine lojistik, otomotiv endüstrisi dışında, çelik, elektronik, bilgisayar, kimya, ilaç, tıbbi araçları da içeren birçok endüstride kullanılmaktadır (Tekin, 2015:29).

$\mathrm{Bu}$ çalışmanın amacı, tersine lojistik ile ilgili olarak son yıllarda yapılan çalışmaların taranması ve araştırmaların yoğunlaştığı konuların belirlenmesidir. Çalışmada "Web of Science (WOS)" veri tabanı kullanılmıştır. 2016-2020 yılları arasını kapsayan taramada "tersine lojistik" anahtar kelimesinin İngilizce olarak kullanıldığı uluslararası dergilerde yayınlanan makaleler incelenmiştir. Çalışma beş bölümden oluşmakta olup birinci bölümde tersine lojistik kavramı, tersine lojistik faaliyetlerindeki engeller, tersine ve ileri lojistik ilişkisi konuları hakkında bilgiler verilmiştir. İkinci bölümde literatür taraması yapılarak tersine lojistik ile ilgili yapılan makale çalışmalarının hangi alanda ve hangi coğrafyada yoğunlaştığı incelenmiştir. Çalışmanın üçüncü bölümünde araştırma metodolojisi bulunmaktadır. Dördüncü bölümde araştırmaya ait bulgular verilmektedir. Son bölümde ise araştırma sonuçları bulunmaktadır. 


\section{TERSINE LOJISTIK}

Tersine ve tersine dağıtım kanalı terimlerinin doğuşu 1970'li yıllara dayanmaktadır (Zikmund ve Stanton, 1971: 34). Ters dağıtım, kullanılmış ürünlerin ve paketlerin toplanması ve taşınmasıdır (Fleischmann, 1997:4). Tersine lojistik çeşitli ürün ve ürün atıklarının imhası gibi faaliyetleri içeren ileri lojistik akışının tersini içeren bir süreçten oluşmaktadır. Tersine lojistik tedarik zincirinin her aşamasına adapte olmaya başlamıştır (Rogers \& Tibben-Lembke, 2001:274). Tersine lojistik süreci, ürünün tasarımdan tüketimine ve geri dönüşümüne kadar tüm yaşam döngüsünü içine almaktadır (Guarnieri vd., 2016:1105). Televizyon, çamaşır makinesi ve buzdolabı gibi birçok ürün teknolojik gelişmeye bağlı olarak eskitildiğinde veya ekonomik ömrünü tamamladığında geri dönüşümle birlikte ekonomiye kazandırılır. Bu bağlamda yapılan bütün işlemler tersine lojistik konusuna girmektedir. Tersine lojistik; çeşitli malzemelerin atık imhası ve geri kazanım işlemlerinden meydana gelen lojistiğe denir (Tekin, 2015:25). Tersine lojistiği anlayabilmek için bu faaliyetlerin boyutlarının incelenmesinde fayda bulunmaktadır. Tersine lojistiği daha iyi analiz edebilmek için kim, ne, niçin ve nasıl gibi soruların cevaplanması gerekir. Bunlar (De Brito, 2003:60-67):

Kim; tersine lojistiğin başkahramanları işletme ve tüketicilerdir. Bu faaliyet işletmeler arasında (B2B) ve işletme ile tüketici (B2C) arasında olabilir. Tersine lojistiğin kimler arasında olduğu dağıtım veya toplama kanallarının belirlenmesi açısından önemlidir.

Ne; tersine lojistiğe giren ürün ile çıkan ürünün ne olduğunun bilinmesi süreçlerin akışı ve değerlendirilmesinde önemli katkılar sağlamaktadır. Tersine lojistikte kullanılan herhangi bir nedenle ömrünü tamamlamış ürünün (elektronik, dayanıklı mal, yiyecek vb.) bilinmesi toplama, depolama ve ulaştırma faaliyetlerinin belirlenmesine katkı sağlayacaktır.

Niçin; tersine lojistik faaliyetinde yapılan işlemlerin niçin yapıldığının bilinmesi amaca uygun hareket edilmesini sağlamaktadır. Ürünün geri çağrılması, müşterinin beğenmemesi, ürün hatası, ürün fazlası gibi sebeplerin bilinmesi yapılacak faaliyetin iş akışının belirlenmesine yardımcı olmaktadır.

Nasıl; lojistik faaliyeti tek merkezden farklı yerlere doğru olmaktadır, tersine lojistik faaliyetinin birçok noktadan tek noktaya doğru olması iş akışının karmaşık hal almasına neden olmaktadır. Tersine lojistikte doğru stratejinin belirlenmesi ürünlerin sorunsuz, zamanında ve uygun maliyette işletmeye ulaşmasını sağlamaktadır.

Tersine lojistik yönetimiyle ilgili daha doğru kararların alınabilmesi için malların toplanması ve toplanan malların sınıflandırılması önemlidir (Dhakal, 2018:15). Sınıflandırmada mallar; kağıt, plastik, içecek depozitoları, metal, yağlar, kimyasallar gibi birçok farklı ürüne ayrılmaktadır (Fleischmann, 1997:3). Şekil 1'de hem ileri doğru hem de tersine lojistik için genel bir tedarik zinciri görünümü verilmiştir (Meade ve Sarkis, 2002:285). Şekilde, ileri lojistik faaliyeti üretim merkezinden kullanıcı yönünde devam eden bir süreci, tersine lojistik faaliyeti kullanıcıdan üretim merkezine doğru bir süreçten meydana geldiğini göstermektedir. İleri lojistikte bir merkezden birçok merkeze doğru dağıtım faaliyeti gerçekleşirken, tersine lojistikte birçok merkezden tek bir merkeze toplanma ve dağıtım faaliyeti yapılmaktadır.

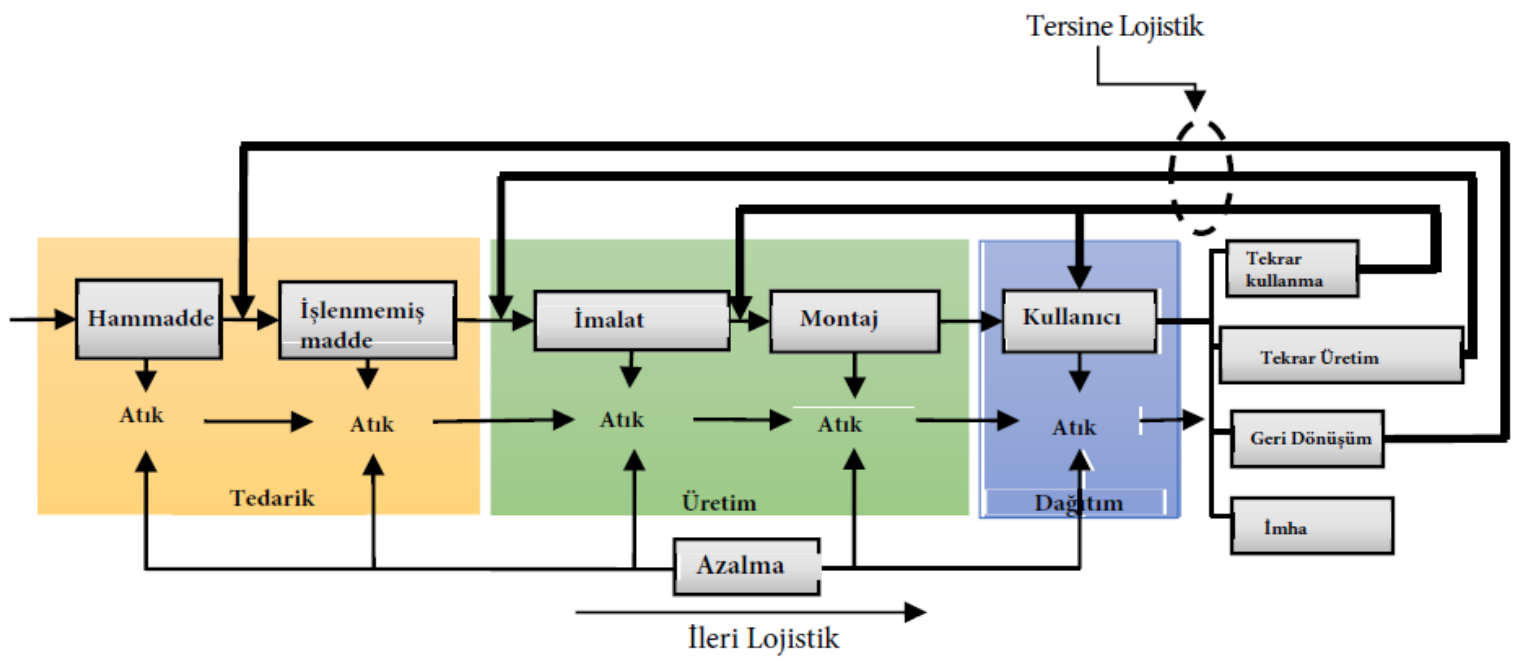

Şekil 1. İleri ve Tersine Lojistik Süreçlerinin Gösterimi

Kaynak: Meade ve Sarkis, 2002:285

Tedarik zinciri yönetimi zaman içerisinde daha fazla önem kazanırken tersine lojistik faaliyetleri tedarik zincirine nazaran daha az dikkate alınmıştır (Rahman, 2003:688). Kaynakların etkin kullanılması, israfın engellenmesi gibi anlayışların oluşmasını 
sağlayan yalın tedarik zinciri anlayışı sonucu geri dönüşüm, tekrar kullanma ve atıkların bertaraf edilmesi konuları ile tersine lojistiğin önemine dikkat çekilmiştir. Tersine lojistik hiyerarşisi zincire değer katacak faaliyetlerin tersine lojistik ve tedarik zincirinin bütününde maliyetlerin azaltılmasını ve kaynakların etkin kullanılmasını amaçlamaktadır (Carter ve Ellram, 1998:85). Tersine lojistik faaliyetleri esnasında toplama, ayrıştırma ve geri üretim merkezine taşınması gibi faaliyetlerin gerçekleştirilmesinde kaynakların etkin kullanılması ve maliyetlerin minimize edilmesi önemlidir.

Aşağıda Şekil 2'de, tersine lojistik hiyerarşisi gösterilmektedir (Carter ve Ellram, 1998). Şekil 2'de görüleceği üzere tersine lojistiğin temel amacı, üretimde girdi olarak kullanılan kaynakların (malzeme, enerji vb.) tüketiminde tasarruf sağlanması sonucunda kaynak kullanımının azaltılmasıdır. Ayrıca tersine lojistik, daha önceki üretilmiş parçaların (hammadde, malzeme, yarı mamul) geri kazanılarak yeniden kullanımını da hedeflemektedir. Bu amaçla tersine lojistikle kullanım dışı kalan atık materyallerin tekrar imalat süreçlerine kazandırılması için geri dönüşüm yapılmaktadır. Tersine lojistikle kullanılamayacak durumda olan malzeme ve ürünler gömme ya da yakma işlemleriyle ortadan kaldırılır.

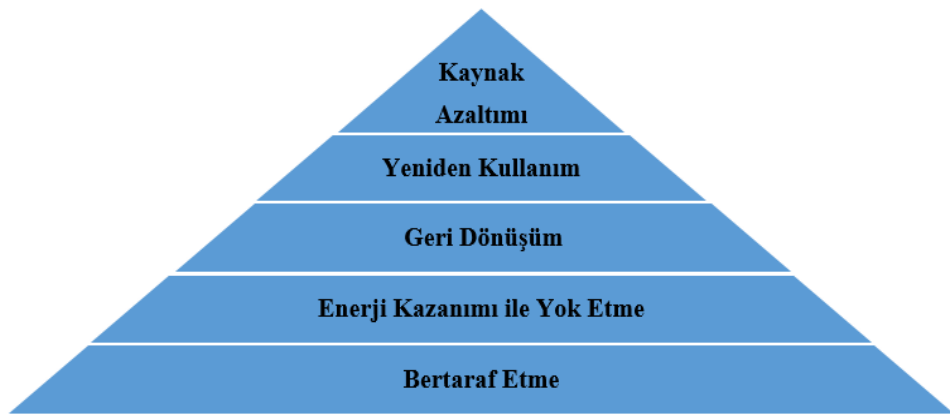

Şekil 2. Tersine Lojistik Hiyerarşisi (Kavramsal bir yapı)

Kaynak: Carter ve Ellram, 1998

Tersine lojistik sadece envanterde maliyet tasarrufu sağlamakla kalmaz, aynı zamanda müşteri sadakatini artırmak için bir araç olarak da kullanılabilir (Hsu, vd., 2016:87). Bazı önemli markaların ürettikleri malların müşterinin eline geçtikten sonra bazı sorunların çıkması nedeniyle kendi istekleri ile dağıtımda olan ve müşterinin aldıkları ürünleri toplatması yine bir tersine lojistik faaliyetidir. Bu örnekler birçok otomobil ve elektronik cihaz üreticilerinde yaşanmıştır.

Tersine lojistik faaliyetlerinin daha iyi anlaşlabilmesi için tersine lojistik bileşenleri incelenmiş ve Tablo 1'deki şekilde sınıflandırılmıştır.

Tablo 1. Tersine Lojistik Bileşenleri

\begin{tabular}{lllll}
\hline Nedir & Girdiler & Faaliyetler & Çıktılar & Nereden \\
\hline Süreç & Atık mallar & Yönetim & Malların tekrar kullanımı & Tüketim noktasından \\
Görev & Kullanılmış mallar & Toplama & Geri dönüşüm & Toplama noktası \\
Beceri & Önceden gönderilmiş & Taşıma & Yeniden üretim & Tekrar toplam noktasına \\
Faaliyet & mal/parçalar & Depolama & İmha & \\
& Paketler & İşleme & Azalma & \\
& Bilgi & Teslim alma & Yöneltme & \\
& Hammadde & Geri dönüşüm & Geri dönüşüm değeri & \\
& Stoklama süreci & Paketleme & & \\
& & Nakliye & & \\
& & Azalma & & \\
& İmha etme & &
\end{tabular}

Kaynak: Rajagopal, vd., 2015:40

Tersine lojistik bileşenlerinin oluşumu son kullanıcıdan tekrar üretim veya ürünün tamamı ile bertaraf edilmesine kadar geçen süreçte yapılan faaliyetlerden oluşmaktadır. Bu faaliyetler; ürünün toplanması, ayrışması, depolanması, tamiri, tekrar üretime kazandırılması, atıkların bütün artıklarının ortadan kaldırılması ve bilgi akışı gibi konuları ele almaktadır. Tersine lojistik kapsamında toplanan ürünler özelliklerine göre veya toplanma yerlerine göre gruplandırılabilir. Bunlar kullanım sonu, garanti kapsamında, ticari, üretim süreci, dağıtım sonucu ve paketleme geri dönüşleri olarak sıralanabilir (Dirik, 2012:61-63). Tedarik zincirinde olduğu gibi tersine lojistik faaliyetlerinde de bilgi teknolojileri önemlidir. Tersine lojistik faaliyetleri birden fazla yerde ve birden fazla işletmelerin koordineli şekilde çalışması ile gerçekleşmektedir. Basit gibi görünen iş akışının farklı işletmeler tarafından koordineli bir şekilde yapılması büyük bir kaos yaratmasının yanı sıra iyi şekilde yönetilirse daha az maliyet ve rekabet avantajı sağlayabilir. Bu karmaşanın iyi yönetilebilmesi için bilgi akışının şeffaf ve herkes tarafından takip edilebilir olması gereklidir. Aşağıdaki Şekil 3'te tersine lojistikte bilgi akışı ve ürün akışı arasındaki ilişki anlatılmaktadır. 


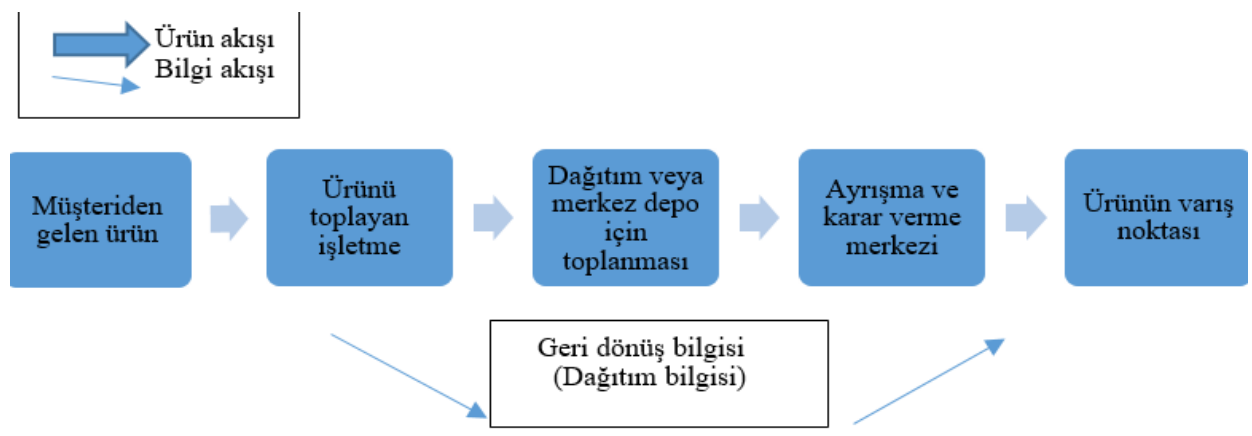

Şekil 3. Perakendeciler İçin Tersine Lojistik Bilgi Akışı

Kaynak: Tibben-Lemke ve Rogers, 2002:273

\subsection{Tersine Lojistik Faaliyetlerindeki Engeller}

Tersine lojistik faaliyetinin birçok faydası olmasına rağmen uygulamasında birçok engeller ortaya çıkmaktadır. Gelişmiş ve gelişmekte olan ülkelerin yasaları, çevreye duyarlılığı, tüketicinin algısı gibi birçok neden bu engelleri oluşturmaktadır. Ülkelere göre farklılık göstermesine rağmen üretim sektöründeki tersine lojistik engelleri yönetim, finansal, politika ve altyap1 olarak 4 ana grupta değerlendirilebilir (Abdulrahman, vd., 2014:465). Bu sınıflandırmada en fazla etkiyi devletlerin çıkardığı yasaların ve lojistik faaliyetleri için gerekli olan alt yapı oluşturduğu söylenebilir (Şekil 4).

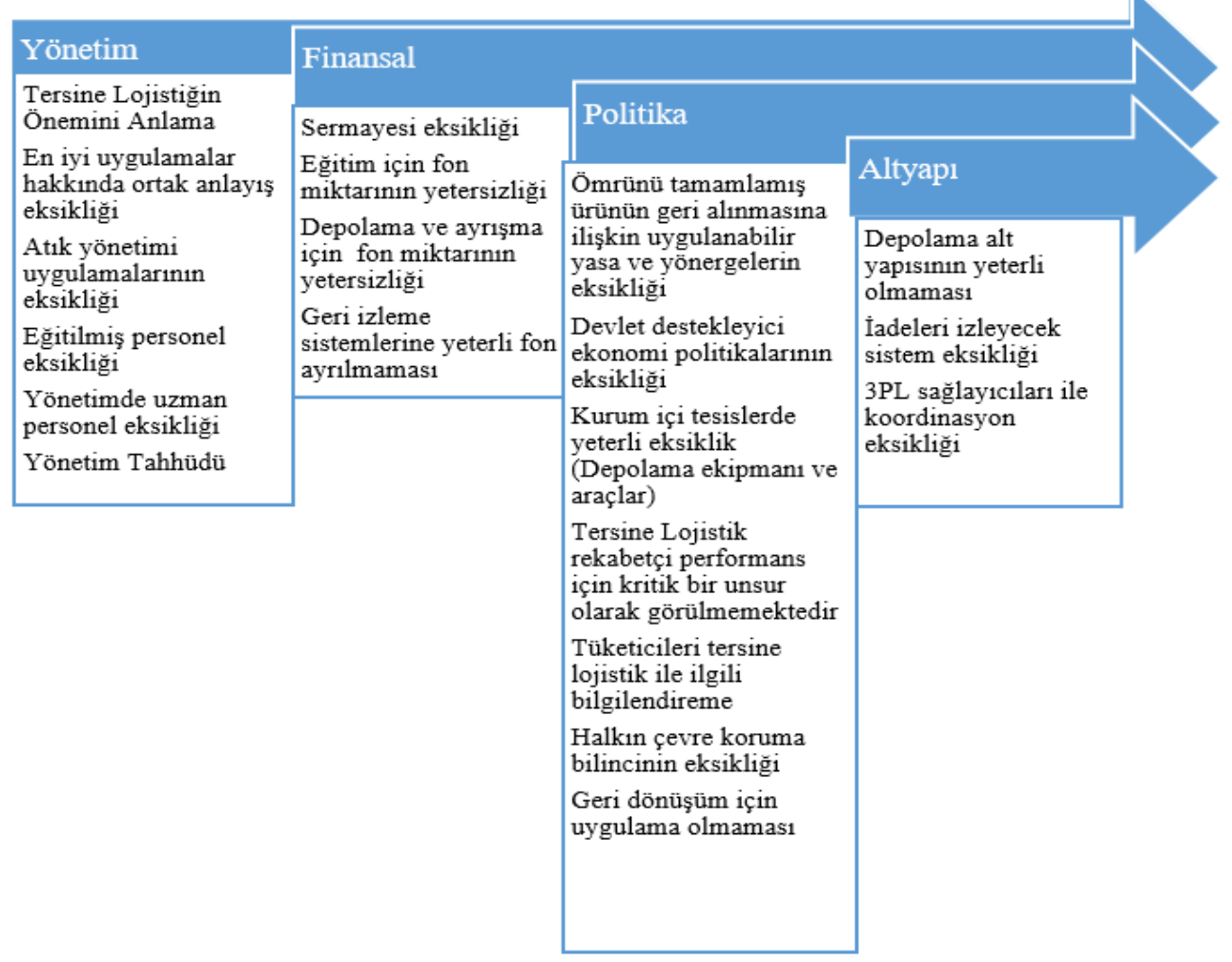

Şekil 4. Tersine Lojistik Engelleri

Kaynak: Abdulrahman, vd., 2014:465

\section{2. İleri ve Tersine Lojistik İlişkisi}

İleri lojistik, malların ve hizmetlerin tüketiciye nasıl ulaştırabileceği konularına yoğunlaşmaktadır. Tersine lojistik ise tüketiciden veya işletmelerden ürünlerin nasıl toplanacağı ve uygun şekilde nasıl değerlendirileceği konularına yoğunlaşmaktadır. İleri lojistikte üretim noktasından birçok noktaya akış olmaktadır. Tersine lojistikte ise birçok noktadan bir noktaya doğru akış olmaktadır (Tibben-Limke ve Rogers, 2002:275). Bu sebepten tersine lojistiğin yönetilmesi ve izlenebilmesi daha karmaşık ve zordur. Aşağıdaki Tablo 2'de ileri ve tersine lojistik arasındaki farklıklar özetlenmiştir. 
Tablo 2. İleri ve Tersine Lojistik Arasındaki Farklılıklar

\begin{tabular}{ll}
\hline İleri Lojistik & Tersine Lojistik \\
\hline Tahmin edilebilir kısmen basittir & Tahmin edebilmek zordur \\
Bir noktadan birçok noktaya dağıtım & Birçok noktadan bir noktaya toplama \\
Ürün kalitesi nettir & Ürün kalitesi net değildir \\
Ürün paketi nettir & Ürün paketi çoğunlukta zarar görmüştür. \\
Rotalaması açıktır & Rotalama açı değildir \\
Standart dağıtım kanalı vardır & Tahmini dağıtım kanalı vardır. \\
Düzenleme opsiyonları açıktır & Düzenleme opsiyonları açık değildir \\
Fiyatlaması kısmen belirgindir & Fiyatlaması belirgin değildir \\
Hız kısmen önemlidir & Hız kısmen önemli değildir \\
Dağıtım kanallarının izlenebilirliği açıktır & Dağıtım kanallarının izlenebilirliği açık değildir \\
Envanter yönetimi tutarlıdır & Envanter yönetimi tutarlı değildir \\
Ürün yaşam döngüsü yönetilebilir & Ürün yaşam döngüsü karmaşıktır \\
Dış kaynak partileri ile görüşme basittir & Dış kaynak partileri ile görüşme karmaşıktır \\
Pazarlama faaliyetleri çok iyi bilinir & Pazarlama faaliyetleri karmaşıktır \\
Gerçek zamanlı bilgi akışı daha kolaydır & Faaliyet takibi daha az şeffaftır \\
\hline
\end{tabular}

Kaynak: Tibben-Limke ve Rogers, 2002:276

\section{LITERATÜR TARAMASI}

Tersine lojistik ile ilgili literatürde çok sayıda çalışma yapılmış olmasına rağmen kısıtlı sayıda tersine lojistiğe ilişkin bibliyometrik analiz çalışmaları bulunmaktadır. Bunlardan bazıları aşağıda verilmiştir.

Agrawal vd., (2015) tersine lojistik ile ilgili yapmış oldukları çalışmalarında uluslararası geçerli veri tabanlarında 1989 ve 2015 yılları arasında yayınlanan makale, kitap ve raporları taramışlardır. Gerekli sınırlamaları yaparak 242 tane çalışmayı alt başlıklar halinde sınıflandırmışlardır. Google-scholar arama motoru ve Scopus veri tabanlarından faydalanmışlardır. Analiz sonuçlarına göre; makalelerin çoğunun Omega, International Journal of Physical Distribution and Logistics Management, Resource, Conservation and Recycling, European Journal of Operational Research, International Journal of Production Research ve International Journal of Production Economics dergilerinde yayınlanmıştır. Konu ile ilgili en fazla makale 2012 yılında (28) yapılmıştır. Betimsel analiz yaparak gelecekte yapılabilecek çalışmalara yardımcı olmayı amaçlamışlardır.

Govindan ve Soleimani (2016) tersine lojistik ile ilgili yapmış oldukları bibliyometrik çalışmalarında 2001-2014 yılları arasında Journal of Cleaner Production dergisinde yayınlanan tersine lojistik ve kapalı döngülü tedarik zinciri ie ilgili 83 adet makale çalışmasını sınıflandırmışlardır. Tersine lojistik ve kapalı döngülü tedarik zinciri üzerine yapılan çalışmaları kategorilere ayırmışlardır. Bu kategoriler; yeniden üretim, atık yönetimi, geri dönüşüm, yeniden kullanım, geri kazanım gibi konularıdır.

Wang vd. (2017), 1992-2015 yılları arasında tersine lojistik alanında yapılan çalışmaları bibliyometrik analiz yöntemiyle incelemişlerdir. Çalışmada tersine lojistik alanında yapılan çalışmaların alana katkılarının belirlenmesi amaçlanmıştır. Web of Science veri tabanından tersine lojistik alanında yayınlanmış 912 makaleyi incelemişlerdir. Analiz sonuçlarına göre; 2009 yılından itibaren tersine lojistik alanındaki çalışmaların hızla arttığı, 2013 yılında en fazla çalışmanın (123) yapıldığı, Guide ve Van Wassenhove tarafindan en fazla atıf alan çalışmaların yapıldığı tespit edilmiştir. Ayrıca; tersine lojistik, yeşil lojistik, tersine lojistik ağı, ürün yaşam döngüsü yönetimi, tedarik zinciri, ürün iadeleri, yeniden üretim, sürdürülebilirlik anahtar kelimelerinin kullanılan en önemli anahtar kelimeler olduğu görülmüştür.

Campos vd. (2017), 1996-2015 yılları arasında ilaç sektöründe tersine lojistik ile ilgili 748 makalenin içerik ve bibliyometrik analizini (VOSviewer) yapmışlardır. Araştırma sonuçlarına göre en çok yayın yapan ülkeler sırasıyla Birleşik Krallık, ABD, İspanya, Almanya, İtalya, Danimarka ve İsveç’tir. En fazla kullanılan anahtar kelime tedarik zinciri yönetimi, en fazla yayın yapan üniversite Cranfield University, en fazla yayının yapıldığı dergi Supply Chain Management dergisidir.

De Lima Simão vd. (2018), tersine lojistik alanında yapılan çalışmaları bibliyometrik analiz yöntemiyle incelemişlerdir. Çalışmalarında tersine lojistikte ortaya çıkan bilimsel ve teknolojik alanları ortaya çıkarmayı amaçlamışlardır. Web of Science veri tabanı kullanılarak tersine lojistik alanındaki 841 çalışma değerlendirmeye alınmıştır. Yapılan analizler sonucunda; tersine lojistik alanında çalışan araştırmacılar, araştırmacıların ülke atıfları ve ağ yoğunluğu gibi hususları belirlemişlerdir.

Kazemi vd. (2019), 2000-2017 yılları arasında tersine lojistik ve kapalı döngü tedarik zinciri yönetimiyle ilgili 94 çalışmanın içeriğini bibliyometrik analiz yöntemiyle incelemişlerdir. Araştırmada VOSviewer programı kullanılarak analizler yapılmıştır. Web of Science ve Scopus veri tabanlarından faydalanılmıştır. Çalışma, International Journal of Production Research (IJPR)'de bu alanlarda yapılan makalelerle sınırlandırılmıştır. En fazla çalışmanın 2012 yılında yayınlandığı, en fazla çalışma yapılan ülkenin ABD olduğu, en sık kullanılan anahtar kelimelerin tersine lojistik, kapalı döngü tedarik zincirive yeniden üretim olduğu görülmüştür. Alana en fazla katkıda bulunan yazarlar ise K. Govindan, L.N. Van Wassenhove ve V.D.R. Guide'dir. Çalışmalarda en fazla kullanılan anahtar kelimelerin başında tersine lojistik, yeniden üretim ve kapalı döngü tedarik zinciri gelmektedir. 
Gallegos vd. (2019), 2005-2019 yılları arasında Web of Science (WOS) veri tabanından tersine lojistik ve yeşil lojistik ile ilgili araştırmaları bibliyometrik bir genel bakış açısıyla karşılaştırmayı amaçlamışlardır. Tersine ve yeşil lojistik konusunda $2005-$ 2019 döneminde yayınlanan makaleler arasında karşılaştırma yapıldığında tersine lojistik alanındaki akademik çalışmaların yeşil lojistik çalışmalarına nazaran her yıl daha yüksek olduğu görülmüştür. Tersine lojistik alanında en fazla yayını olan yazarların Govindan, K. (13), Hazen, Bt. (8), Hanna, Jb. (7), Lee, Dh. (7), Chileshe N. (6) olduğu tespit edilmiştir. Tersine lojistik ve yeşil lojistik alanında akademik üretimin en yüksek olduğu ülkelere bakıldığında; tersine lojistikte ilk üç ülke Birleşik Devletler, Brezilye ve Çin olarak sıralanırken, yeşil lojistikte bu ülkeler Çin, Birleşik Devletler ve İngiltere olarak gerçekleşmiştir. Tersine lojistik alanında akademik üretimin en yüksek olduğu üniversite Güney Danimarka Üniversitesi olurken, yeşil lojistik alanında akademik üretimin en yüksek olduğu üniversite Hong Kong Politeknik Üniversitesi olarak bulunmuştur.

Chaves vd. (2019), 2004-2018 yılları arasında Science Direct ve Web of Science (WOS) veri tabanlarındaki tersine lojistikle ilgili 462 makaleyi bibliyometrik ve sistematik analiz yoluyla incelemişlerdir. Tersine lojistikle ilgili en fazla yayının ve atıfın 2017 yılında yapıldığı tespit edilmiştir. Melo, Nickel ve Saldanha-da-Gama'nın (2009) çalışmalarının toplam atıfı en fazla olan çalışma olduğu görülürken, Govindan, Soleimani ve Kannan'ın (2015) çalışmalarının ise yılda en yüksek atıf sayısına sahip çalışma olduğu görülmüştür. Tersine lojistik konusunda en çok yayınlanan ilk üç dergi yayın sayısına göre sırasıyla; International Journal of Production Economics (74), Journal of Cleaner Production (66), Resources, Conservation and Recycling (33) şeklinde sıralanmıştır. Tersine lojistikle ilgili en çok yayın yapan kurumların başında 2014 yılında 13 yayınla Güney Danimarka Üniversitesi (Danimarka) gelmektedir. Bunu 2010 y1lında 9 yayınla Ryerson Üniversitesi (Kanada), 2009 yılında 9 yayınla Nanyang Teknoloji Üniversitesi (Singapur) ve 2015 yılında 5 yayınla Santa Catarina Federal Üniversitesi (Brezilya) izlemiştir.

Kosacka-Olejnık ve Werner-Lewandowska (2020) tersine lojistik başlığı altında son 40 yılda yayınlanan makaleleri sınıflandırmışlardır. Çalışma yaparken Web of Science ve Scopus veri tabanlarını kullanmışlardır. Ülkelere, konu başlıklarına, dergilere ve yayın yıllarına göre sınıflandırmaların yapıldığı çalışmalarında, tersine lojistik ile ilgili popüler çalışmaları göstermişlerdir.

Alkan vd. (2020), 2000-2019 yılları arasında Web of Science (WOS) veri tabanından alınan tersine lojistik ile ilgili 1850 makalenin içeriğini bibliyometrik analiz yöntemi ile incelemişlerdir. Yapılan analizler sonucunda tersine lojistik alanında yapılan yayınlarda en yüksek atıf sayısının 2000 yılında gerçekleştiği, en sık kullanılan anahtar kelimenin yönetim olduğu, tersine lojistik kavramının 2007 yılından sonra daha sık kullanıldı̆̆ı, en fazla makale yayınlayan derginin Journal of Cleaner Production, en fazla yayın yapan üniversitenin Tahran Üniversitesi, en fazla yayın yapan araştırmacının Kannan Govindan olduğu ve bu alanda en fazla çalışma yapan ülkenin ABD olduğu sonucuna ulaşılmıştır. Çalışmada bibliyometrik analiz R programı ile gerçekleştirilmiştir.

\section{ARAŞTIRMA YÖNTEMI}

Bu çalışmada, uluslararası düzeyde kabul görmüş veri tabanlarında 2016-2020 yılları arasında tersine lojistikle ilgili yayınlanan çalışmaların incelenmesi için bibliyometrik analiz yöntemi kullanılmıştır. Bibliyografya, belli bir konu, yer ve dönemle ilgili olan yayınlar ve eserlerden oluşmaktadır. Bibliyografyanın amacı bu eserler içerisinden en iyilerini seçmeye dayalı olarak araştırma ve inceleme yapılarak belge ve kaynakça oluşturmaktır. Bibliyometri, bir konudaki bibliyografya özelliklerinin sayısal analizidir. Bu bağlamda bibliyometri kavramı, bibloyografya olarak yayınlanan eserlerin bibliyografik bilgilerini sayısal olarak incelemek üzere ilk kez 1969 yılında kullanılmıştır. Bibliyometrik analizin amacı bir bilim ya da konuyla ilgili yayınlar arasındaki ilişkilerin sayısal olarak değerlendirilmesidir. Dolayısıyla bibliyometrik analiz yöntemi yazında mevcut olan tüm kaynakların (makale, kitap ve ilgili tüm dokümanlar) ve istatistiklerin birleştirilmesi, yorumlanması ve analiz edilmesi sonucunda bir disiplinin doğasının ve gelişim sürecinin tespit edilmesi amacıyla yapılan analizleri kapsamaktadır. Tersine lojistikle ilgili bibliyometrik analiz bulguları matematiksel ve istatistiksel olarak araştırmacıların yapacağı tersine lojistik yazınsal çalışmalarının oluşum ve gelişim sürecine yol gösterici olarak ışık tutmaktadır (Lawani, 1981: 295). Özellikle son yıllarda bibliyometrik analiz araştırma değerlendirme yönteminin önemli bir parçası haline gelerek bilimsel ve uygulamalı alanlarda yaygın olarak kullanılmaktadır.

Web of Science veri tabanında mevcut olan dergilerin makaleleri değerlendirilmiştir. Bu veri tabanının seçilmesinin nedeni dünya çapındaki araştırmacılar tarafından en çok tercih edilen veri tabanlarından birisi olmasıdır. Çalışmanın konu başlığı "tersine lojistik" olarak belirlendikten sonra aşağıdaki işlem basamakları takip edilmiştir. 


\title{
Selçuk Üniversitesi Kütüphanesi Veritabanına uzaktan giriş yapıldı
}

\author{
Veritabanı belirlendi (Web of Science)
}

"Tersine Lojistik" anahtar kelimesi ile arama yapıldı (2016-2020 yılları arası kısıtlama yapıldı)

182 adet makale bulundu. (Bu arama sonucu sadece SCI, SSCI ve H\&HCI atıflı makalelerden oluşmaktadır)

VOSviewer programı ile bilgi haritalama yapılmış ve veriler değerlendirmeye alınmıştır.

Şekil 5. Çalışma Aşamaları

Tersine lojistik bibliyometrik analizi için veri taraması 24 Nisan 2020 tarihinde yapılmıştır. İlk tarama kısıtlaması 2016-2020 tarihleri arasında, dili İngilizce olan, SCI-Expanded (Science Citation Index Expanded), SSCI (Social Science Citation Index) ve A\&HCI (Art\&Humanities Citation Index) olarak yapılarak 193 adet çalışma bulunmuştur. İkinci kısıtlamada sadece makale (artical) türünde yayınlanmış olan yayınların seçilmesi ile 182 adet çalışma bulunmuştur. Analizler VOSviewer paket programı ile yapılmış ve görselleştirilmiştir.

\section{1. Çalışmanın Amacı ve Kapsamı}

Çalışmanın amacı, tersine lojistik ile ilgili olarak son yıllarda yapılan çalışmaların taranması ve araştırmaların yoğunlaştığı konuların, coğrafyanın, araştırmacıların belirlenmesidir. Son yıllarda dünyadaki ekosistemde, küresel ve yerel ekonomide, sanayide ve işletmelerde eko sürdürülebilirliğin önem kazanması ve tersine lojistiğin sağladığı rekabet avantajları kapsamında tersine lojistik kavramının önemi artmıştır. Araştırmacıların tersine lojistik faaliyetleri kapsamında karbon ayak izi, karbon emisyon, yeniden üretim, geri dönüşüm, atık yönetimi, ağ tasarımı, tersine lojistik ağı, tedarik zinciri, tedarik zinciri yönetimi, sürdürülebilirlik, belirsizlik ve döngüsel ekonomi konularını da çalışmışlardır.

Araştırmanın kapsamı uluslararası alanda talep gören "Web of Science" veri tabanında mevcut olan dergilerde yayınlanmış makalelerdir. Çalışmada tercih edilen bütün makalelerin dili İngilizcedir. Bu konu ile ilgili güncel konuların tespit edilmesi için çalışmada 2016-2020 yılları arasında yayınlanmış makaleler inceleme kapsamına alınmıştır. Tersine lojistik konusunun dünyadaki kaynakların azalması ve küresel ısınmanın etkilerinin artması sonucunda mevcut kaynakların geri dönüşümle ekonomiye kazandırılmasının özellikle son beş yıl içerisinde önem kazanarak tersine lojistikle ilgili yayınların artmasından dolayı bu dönem çalışmaya esas alınmıştır. İlgili veri tabanının arama kısmına başlık ve konu olarak "reverse logistics (tersine lojistik)" ifadesi yazılarak arama yapılmıştır. İlk arama sonucunda 193 adet sonuç çıkmıştır. Bu sonuç sonrasında konferanslarda sunulan bildiri çalışmalarının çıkartılmasıyla toplamda 182 adet makale değerlendirmeye alınmıştır. Kriterlere uygun 182 makale; yazarları, anahtar kelimeler, kullanılan kelimelerin yoğunluğu, yayın yapan ülkeler, yayın yapan dergiler ve yayın yapan üniversiteler başlıkları altında sınıflandırma yapılmıştır. Araştırma için belirlenen süre içerisinde üç taneden az yayın yapan, ülkeler, dergiler ve üniversiteler şekil karmaşası yaşanmaması için şekillere eklenmemiştir.

\section{BULGULAR}

Tersine lojistik ile ilgili hazırlanan bibliyometrik çalışmada, 2006-2020 yıllarına ait toplam 182 makale WOS veri tabanı üzerinden elde edilmiştir. Şekil 6 ve Tablo 3'de tersine lojistikle ilgili atıf yapılan ülkelere ve bu ülkelerin yayın adedi, atıf puanı ve toplam bağlantı miktarlarına ilişkin bilgilere yer verilmiştir.

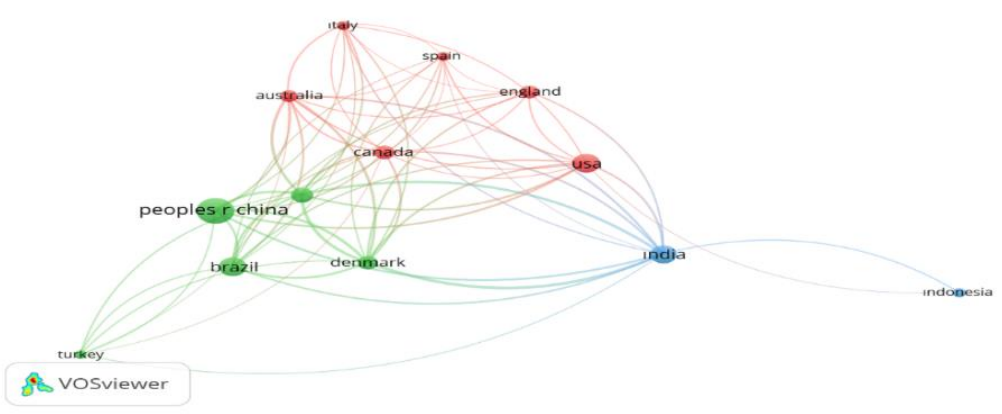

Şekil 6. Tersine Lojistik ile İlgili Atıf Yapılan Ülkelerin Dağılımı 
Şekil 6 incelendiğinde tersine lojistik ile ilgili atıf yapılan ülkelerin ilişki durumlarına göre yeşil renk ile; Çin, Brezilya, Danimarka, Türkiye, kırmızı renk ile; Kanada, ABD, İngiltere, İspanya, Avustralya ve mavi renk ile; Hindistan ve Endonezya arasında daha yoğun ilişki olduğu görülmektedir.

Tablo 3. Tersine Lojistik ile İlgili Atıf Yapılan Ülkelerin Yayın Adedi, Atıf Puanı ve Toplam Bağlantı Miktarlarına Göre Dağılımı

\begin{tabular}{|c|c|c|c|}
\hline Ülke adı & Yayın adedi & Atıf puanı & Toplam Bağlantı Miktarı \\
\hline Danimarka & 13 & 464 & 154 \\
\hline İran & 16 & 424 & 147 \\
\hline Hindistan & 23 & 341 & 136 \\
\hline Çin & 44 & 334 & 106 \\
\hline Avusturalya & 10 & 124 & 89 \\
\hline Brezilya & 22 & 223 & 77 \\
\hline $\mathrm{ABD}$ & 24 & 302 & 74 \\
\hline Kanada & 13 & 180 & 55 \\
\hline İngiltere & 12 & 120 & 35 \\
\hline İtalya & 6 & 167 & 31 \\
\hline İspanya & 6 & 59 & 23 \\
\hline Türkiye & 5 & 82 & 20 \\
\hline Endonezya & 6 & 42 & 5 \\
\hline Toplam & 200 & & \\
\hline
\end{tabular}

Not: Toplam makale sayısının 182 den fazla çıkmasının nedeni bir makalenin farklı ülkelerdeki yazarlarının birlikte çalışma yapmasıdır.

Tablo 3 incelendiğinde; tersine lojistik ile ilgili olarak 2016-2020 yılları arasında yayınlanan makale sayısı en fazla olan ülke Çin Halk Cumhuriyeti'dir. Çin Halk Cumhuriyeti'ni sırasıyla; ABD, Hindistan ve Brezilya izlemektedir. Tersine lojistik ile ilgili atıf yapılan ülkelerin atıf puanına göre dağılımı sırasıyla; Danimarka, İran, Hindistan, Çin, Avustralya, Brezilya, ABD, Kanada, İngiltere, İtalya, İspanya, Türkiye ve Endonezya olduğu görülmektedir. Tabloda en çok yayın sayısı Çin'de olmasına rağmen toplam atıf yoğunluğu Danimarka'dır. Yayınlanan makalelerin diğer araştırmacılar tarafindan kullanılması ve desteklenmesi, çalışmanın atıf değerini artırmaktadır. Tersine lojistikle ilgili makalelerin yıllara göre dağılımı Şekil 7'de gösterilmiştir.

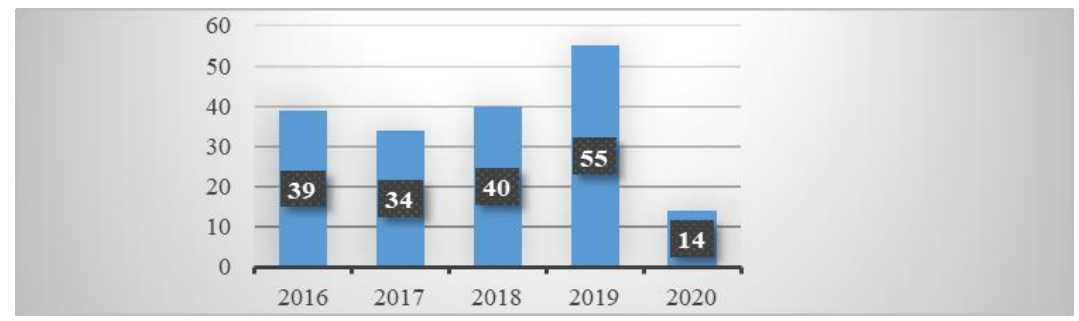

Şekil 7. Tersine Lojistik İle İlgili Makalelerin Yıllara Göre Dağılımı

Şekil 7 incelendiğinde; tersine lojistikle ilgili olarak en fazla yayın 55 makale ile 2019 yılında yapılmış ve onu sırasıyla; 40 makale ile 2018 yıl1, 39 makale ile 2016 yılı, 34 makale ile 2017 yılı ve 14 makale ile 2020 yılı izlemektedir.

Aşağıda Şekil 8'de verilen haritalama ağ tasarımı, tersine lojistikle ilgili en fazla atıf alan araştırmacıları göstermektedir.

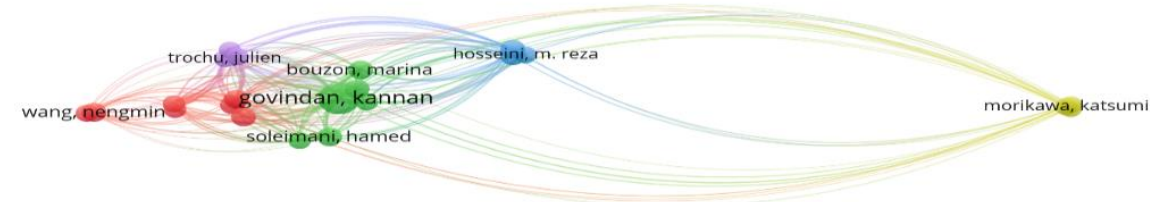

Gosviewer

Şekil 8. Tersine Lojistik ile İlgili En Fazla Atıf Alan Araştırmacılar

Tablo 4'de tersine lojistik ile ilgili en fazla atıf alan araştırmacıların makale miktarı, atıf miktarı ve toplam bağlantı yoğunluğu dağılımı sunulmuştur. 
Tablo 4. Tersine Lojistik ile İlgili En Fazla Atıf Alan Araştırmacılar

\begin{tabular}{lccc}
\hline Yazar & Makale Miktarı & Atıf & Toplam Bağlantı Yoğunluğu \\
\hline Govindan, K. & 10 & 430 & 2981 \\
Bouzon, M. & 4 & 123 & 1344 \\
Soleimani, H. & 4 & 200 & 1267 \\
Solvang, W. D. & 4 & 53 & 1249 \\
Yu, H. & 4 & 53 & 1249 \\
\hline
\end{tabular}

Tablo 4'de görüldüğü gibi Kannan Govindan 10 makale ile tersine lojistik alanında en fazla çalışan ve 430 atıf ile en fazla atıf alan yazardır. Araştırmacı Marina Bouzon'un, atıf miktarının Hamed Soleimani’ye göre daha az olmasına rağmen toplam bağlantı yoğunluğunun daha fazla olduğu dikkat çekmektedir. Şekil 9'da tersine lojistik çalışmalarında yer verilen anahtar kelimeler incelenmiştir.

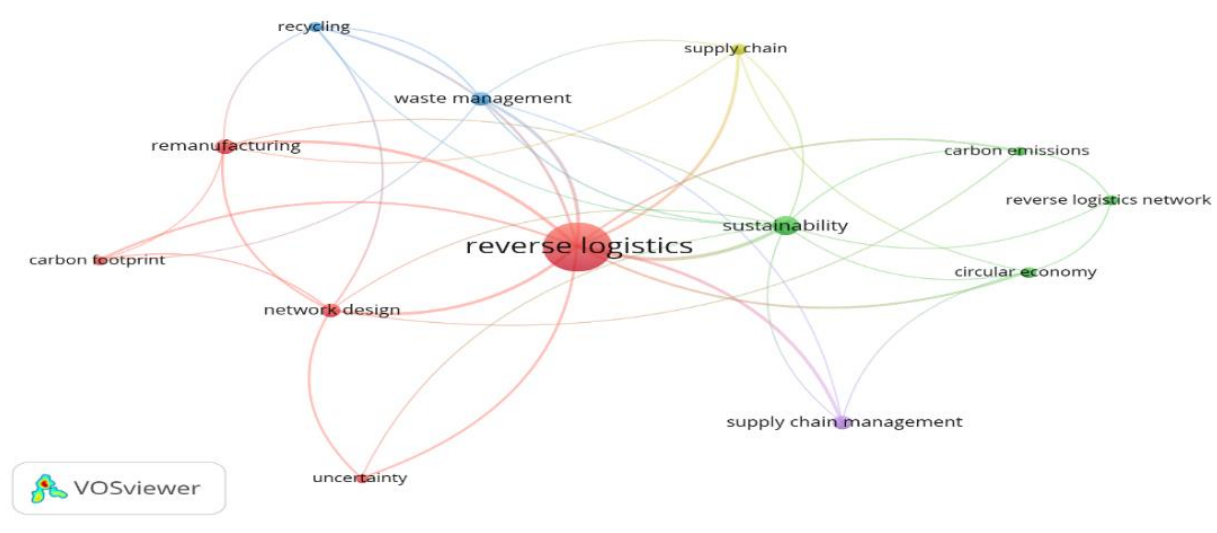

Şekil 9. Anahtar Kelimeler Kapsamında Dağılım

Araştırma kapsamında en fazla kullanılan anahtar kelimelerin sırasıyla; tersine lojistik (129), sürdürülebilirlik (21) ve ağ tasarımı (11) olduğu belirlenmiştir. Tersine lojistikle ilgili kelimelere bağl1 kavramların; atık yönetimi, geri dönüşüm, karbon ayak izi, karbon emisyonu, yeniden üretim, ağ tasarımı, tersine lojistik ağı, tedarik zinciri, tedarik zinciri yönetimi, sürdürülebilirlik, belirsizlik ve döngüsel ekonomi konuları olarak incelendiği görülmektedir (Şekil 9). Anahtar kelime olarak en fazla "tersine lojistik" kavramının çıkması araştırmanın tersine lojistik ile ilgili çalışmaların analiz edilmesinden kaynaklanmaktadır. Ayrıca "sürdürülebilirlik" ve "ağ tasarımı" kavramlarının öne çıkması, bu kavramların tersine lojistik konusu altında son zamanlarda trend olduğunu da göstermektedir. Tersine lojistik (129) anahtar kelimesinin en fazla kullanılan anahtar kelime olması; üretim sırasında ortaya çıkan karbon salınımı ve atıklar sonucunda küresel iklim değişikliği ile birlikte sürdülebilirlik sorununun önem kazanmış olmasından kaynaklanmaktadır. Bu bağlamda tersine lojistik, atık yönetimiyle birlikte geri dönüşümle sağlanan maddelerin ve malzemelerin yeniden üretimle ekonomiye kazandırılarak küresel sürdürülebilirliğe de önemli bir katkı sağlamaktadır. Sürdürülebilirlik (21) kavramının en fazla kullanılan anahtar kelime sıralamasında ikinci sırada olması bu kavramın; karbon ayak izi, karbon emisyonu, döngüsel ekonomi ve belirsizliğe bağlı olarak tersine lojistik altında incelendiğini göstermektedir. Ağ tasarımı (11) kavramının en fazla kullanılan anahtar kelime sıralamasında üçüncü sırada olması bu kavramın; tersine lojistik ağı, tedarik zinciri ve tedarik zinciri yönetimi ağının tasarımının tersine lojistik altında incelendiğini ifade etmektedir. Çalışmaya göre tersine lojistik, sürdürülebilirlik ve ağ tasarımının birbirini etkilemesi beklenen bir sonuçtur. Küresel olarak sürdürülebilirliğin sağlanabilmesi için tedarik zinciri ağ tasarlanarak tersine lojistik işlemleri yönetilmelidir. Tersine lojistik çalışmalarında ön plana çıkan anahtar kelimeler Kelime Bulutuyla daha ayrıntılı incelenerek aşağıda Şekil 10'da görselleştirilmiştir. 


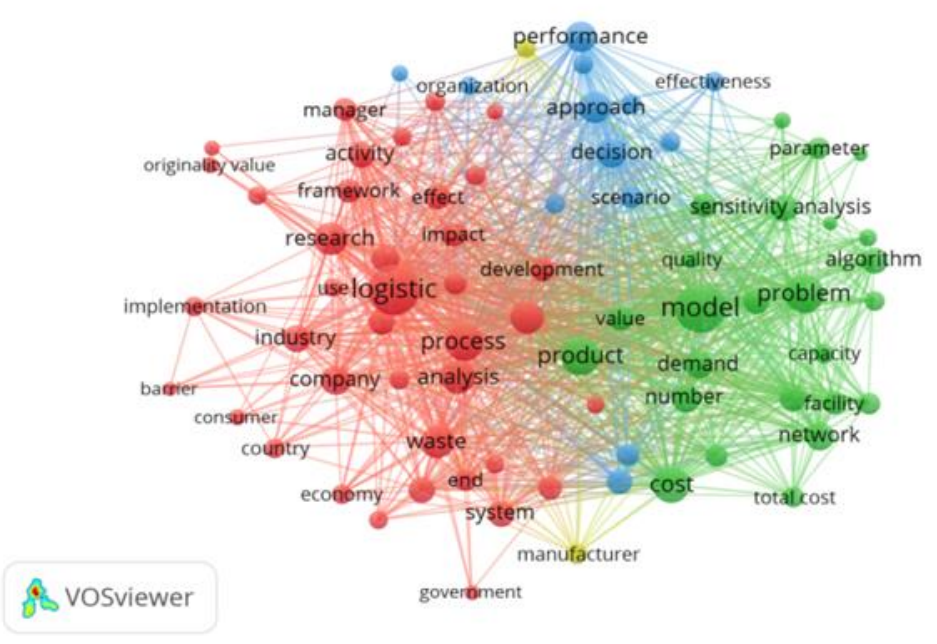

Şekil 10. Kelime Bulutu

Şekil 10 incelendiğinde tersine lojistik çalışmalarında "lojistik", “model”, “problem”, “ürün”, “süreç”, “fiyat”, “atık” kavramlarının sıklıkla kullanıldığı tespit edilmiştir. Kelime bulutuna göre sık olarak kullanılan diğer kavramlar; analiz, ekonomi, araştırma, şirket, senaryo, talep, kalite, ağ, toplam maliyet, etki, gelişme, etkinlik, yaklaşım, ülke, tüketici, özgün değer, sanayi, engeller, sayı, imkânlar, duyarlılık analizi, karar, değişkenler, etkinlik, organizasyon, yönetici, performans, değer, etkileşim, sistem, yaklaşım ve etkidir. Bütün kelime bulutunu oluşturan bu kavramlar tersine lojistik faaliyetleriyle ilgilidir. Çalışmanın ana konusu lojistik üzerine olduğu için "lojistik" kelimesinin fazla kullanılması gözardı edilmelidir. Lojistik kelimesi kadar çok kullanılan "model” kelimesi en fazla kullanılan kelimedir. Ortaya çıkan bu kelimeler, tersine lojistik ile ilgili kavramsal çalışmaların ürün veya atık toplama problemlerinin çözümlerinde kullanılan model çalışmalara yoğunlaşıldığını göstermektedir. Şekil 11'de tersine lojistik ile ilgili 182 makalenin yayınlandığı dergilerin dağılımı gösterilmiştir.

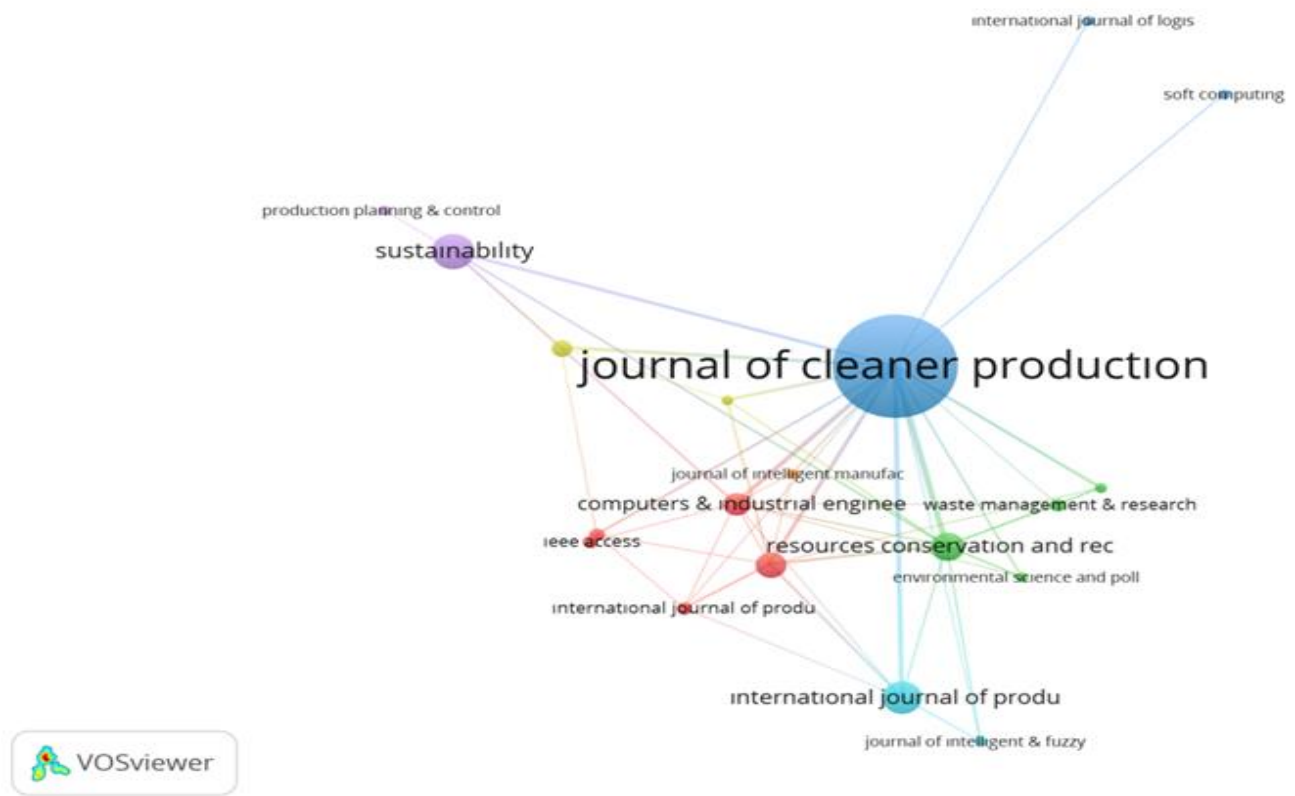

Şekil 11. Yayınlanan Dergi Dağılımı

Şekil 11'e göre; 2016-2020 yılları arasında tersine lojistik ile ilgili en fazla yayın yapan dergi "Journal of Cleaner Production" (40) dergisidir. Bu dergiyi sırasıyla; 12 makale ile Sustainability dergisi, 11 makale ile International Journal of Production Economics dergisi, 9 makale ile Resources Conservation and Recycling dergisi, 8 makale ile Annals of Operations Research dergisi ve 7 makale ile Computers \&Industrial Engineering dergisinin izlediği tespit edilmiştir. 


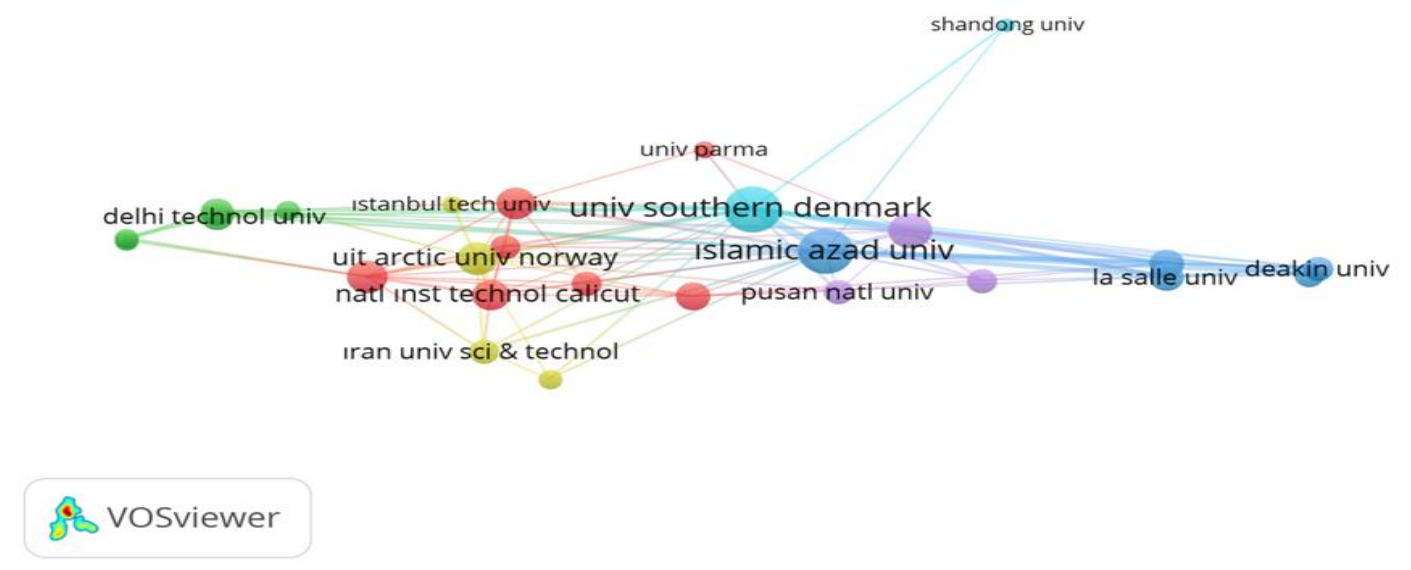

Şekil 12. Çalışma Yapan Üniversitelerin Dağılımı

Tersine lojistikle ilgili çalışma yapan üniversitelerin dağılımı Şekil 12'de görülmektedir. Tersine lojistik ile ilgili en fazla yayın yapan dört üniversite; "University of Southern Denmark" (10 adet ), "Islamic Azad University" (9 adet), "UIT The Arctic University of Norway" (5 adet) ve "Xi'an Jiaotong University" (5 adet) olarak siralanmaktadır.

\section{SONUC}

Bir ürünün tasarım aşamasından itibaren tüm süreçlerinin planlanmasına ve son müşteriye ulaşmasına kadar lojistik odaklı hareket edilmesi zorunlu hale gelmiştir. Bunun sonucunda lojistik tüm işletme faaliyetlerinin merkezinde yer alan ve rekabet avantajı sağlayan lojistik işlemleri olmaksızın hiçbir işletme faaliyetini yapabilmek neredeyse imkânsızdır (Tekin, 2015:4). Aynı durum döngüsel ekonomi ve sürdürülebilirlik açısından tersine lojistik faaliyetleri için de geçerlidir. Tersine lojistiğin temel amacı, üretimde girdi olarak kullanılan kaynakların tüketiminde tasarruf sağlanması sonucunda kaynak kullanımının azaltılmasıdır. Ayrıca tersine lojistik, daha önceki üretilmiş parçaların geri kazanılarak yeniden kullanımını da hedeflemektedir. Tersine lojistik kaynakların etkin kullanılması, israfın engellenmesi gibi anlayışların oluşmasını sağlayan yalın tedarik zinciri anlayışı sonucu geri dönüşüm, tekrar kullanma ve atıkların bertaraf edilmesini de sağlamaktadır. Tersine lojistik hiyerarşisi tedarik zincirine değer katacak faaliyetlerle tedarik zincirindeki maliyetlerin azaltılmasını ve kaynakların etkin kullanılmasını da amaçlamaktadır. Tersine lojistik bileşenlerinin oluşumu son kullanıcıdan tekrar üretim veya ürünün tamamı ile bertaraf edilmesine kadar geçen süreçte yapılan faaliyetlerden oluşmaktadır. Bu faaliyetler; ürünün toplanması, ayrışması, depolanması, tamiri, tekrar üretime kazandırılması, atıkların bütün artıklarının ortadan kaldırılması ve bilgi akışı gibi konuları ele almaktadır. Tersine lojistik süreçlerinin yönetiminde doğru karar verebilmek için çevrimiçi tedarik zincirinde lojistiğe uygun ağın tasarımı gerekir. Bu aşamada tersine lojistik süreçleri tedarik zinciri ağ tasarımı amacıyla çeşitli modellere göre bilgisayar programları kullanılabilmektedir.

Tersine lojistik ile ilgili makaleler incelendiğinde dünyanın mevcut durumu ve geleceği için kritik öneme sahip olan; karbon ayak izi, karbon emisyonu, yeniden üretim, geri dönüşüm, atık yönetimi, ağ tasarımı, tersine lojistik ağı, tedarik zinciri, tedarik zinciri yönetimi, sürdürülebilirlik, belirsizlik ve döngüsel ekonomi konularının incelendiği görülmektedir. Yapılan araştırma sonuçlarına göre makalelerde sürdürülebilirlik kelimesi tersine lojistik kelimesinden sonra en sık kullanılan anahtar kelimedir. Bu çalışmada tersine lojistik (129) anahtar kelimesinin en fazla kullanılan anahtar kelime olması, üretim sırasında ortaya çıkan karbon salınımı ve atıklar sonucunda küresel iklim değişikliği ile birlikte sürdürülebilirlik sorunun önem kazanmış olmasından kaynaklanmaktadır. Bu bağlamda tersine lojistik, atık yönetimiyle birlikte geri dönüşümle sağlanan maddelerin ve malzemelerin yeniden üretimle ekonomiye kazandırılarak küresel sürdürülebilirliğe de önemli bir katkı sağlamaktadır. Bu çalışmada tersine lojistik çalışmalarında ön plana çıkan anahtar kelimelerin kelime bulutuna göre dağılımı da incelenmiştir. Buna göre tersine lojistik çalışmalarında; lojistik, model, problem, ürün, süreç, fiyat, atık kavramları sıkça kullanılmıştır. Kelime bulutuna göre sık olarak kullanılan diğer kavramlar; analiz, ekonomi, araştırma, şirket, senaryo, talep, kalite, ağ, toplam maliyet, etki, gelişme, etkinlik, yaklaşım, ülke, tüketici, özgün değer, sanayi, engeller, sayı, imkânlar, duyarlılık analizi, karar, değişkenler, etkinlik, organizasyon, yönetici, performans, değer, etkileşim, sistem, yaklaşım ve etkidir. Çalışmadaki kelime bulutunu oluşturan bütün bu kavramların tersine lojistiğin gelişmeden kaliteye, organizasyondan sanayiye kadar çok çeşitli kavramlarla ilgili konulardaki faaliyetleriyle ilgili olduğunu göstermektedir. 
Araştırma sonuçlarına göre tersine lojistik ile ilgili olarak 2016-2020 yılları arasında yayınlanan makale sayısı en fazla olan ülkeler sırasıyla; Çin Halk Cumhuriyeti, ABD, Hindistan ve Brezilya'dır. Çevre ve hava kirliliğinin küresel boyutta en fazla yaşandığı ülkelerin başında Çin Halk Cumhuriyeti gelmektedir. Çin'in mevcut üretim sisteminin ortaya çıkardığı aşırı karbon salınımına göre yaşadığı çevresel afetlerin hızla artması sonucu giderek artan çevresel kaygılarla birlikte kaynakların geri dönüşümüyle çevre dostu üretim için tersine lojistik çalışmalarına ağırlık vermeleri önemli bir faktör olabilir. Ayrıca, Çin Halik Cumhuriyeti’nin; dünyanın en büyük üretici ülkesi olması, en büyük ekonomilerinden birisi olması ve en fazla nüfusa sahip ülke olmasından dolayı bu ülkede geri dönüşümle kaynakların ekonomiye kazandırılarak sürdürülebilirlik ve tedarik zinciri ağı tasarımına katkı sağlaması açısından tersine lojistik araştırma sayısının da fazla olması normaldir. Tersine lojistik ile ilgili makale atıfları incelendiğinde, son beş yılda en fazla atıf yoğunluğuna sahip ülkenin Danimarka olduğu ve bunu İran'ın izlediği görülmüştür.

Tersine lojistikle ilgili olarak en fazla yayın 55 makale ile 2019 yılında yapılmış ve onu sırasıyla; 40 makale ile 2018 yılı, 39 makale ile 2016 yılı, 34 makale ile 2017 yılı ve 14 makale ile 2020 yılı izlemektedir. 2020 yılında tersine lojistik ile ilgili yayınlanan makale sayısının diğer yıllara göre çok düşük olmasının nedeninin Covid 19 pandemi koşullarının yayınları olumsuz etkilemesinden kaynaklı olduğu düşünülebilir. Diğer yıllar arasında dikkate değer bir farklılık olduğu göze çarpmaktadır. En fazla yayın yapan ve atıf yoğunluğuna sahip olan araştırmacı ise Kannan Govindan'dır. Gallegos vd. (2019), Kazemi vd., (2019) ve Alkan vd., (2020) yapmış oldukları çalışmalarında alana en fazla katkıda bulunan yazarların başında Kannan Govindan'ın geldiğini tespit etmişlerdir. Yapılan çalışmada yayınlanmış makale miktarı ile atıf miktar yoğunluğu arasında doğru orantı olmadığı görülmektedir. Bu nedenle araştırmacılara etkin bilimsel makaleler yapması önerilebilir. Araştırmada dikkat çeken diğer bir sonuç ise, makale çalışmalarında sürdürülebilirlik ve ağ tasarımı konularının güncel ve popüler olduğu değerlendirmesi yapılabilir. Tersine lojistikle ilgili en çok yayın yapan kurumların başında Güney Danimarka Üniversitesi (Danimarka) gelmektedir. 2016-2020 yılları arasında tersine lojistik ile ilgili en fazla makalenin 2019 yılında yapıldığı görülmüştür. Tersine lojistikle ilgili en fazla yayın yapan derginin "Journal of Cleaner Production" dergisi olduğu sonucuna ulaşılmıştır. Araştırma sonucu elde edilen bu sonuç literatürde Alkan vd., (2020) tarafından yapılan çalışma sonuçlarıyla benzer bulunmuştur. Ayrıca literaürde; Omega (Agrawal vd., 2015), Supply Chain Management (Campos vd., 2017) ve International Journal of Production Economics (Chaves vd., 2019) gibi dergilerin de tersine lojistikle ilgili en fazla yayın yapan dergiler arasında olduğu görülmüştür. Tersine lojistik alanında yapılan makalelerde en fazla kullanılan kelimenin ise "model" kelimesi olduğu tespit edilmiştir.

Araştırma sonuçlarının gelecekte bu konuda yapılacak çalışmalarda araştırmacılara yol göstermesi beklenmektedir. Bulgular kısmında bulunan bilgiler kapsamında araştırmacılara makale konusu seçiminde fikir verebileceği tahmin edilmektedir. Gelecekte konuyla ilgili bilimsel çalışmalar için Türkiye'den yurt dışına gitmeyi planlayan lisansüstü öğrencilere de ülke/araştırmacı vb. yönleriyle katkı sağlayabilir. Bu çalışma, bibliyometrik analiz yöntemiyle tersine lojistiğin İngilizce olarak kullanıldığı uluslararası dergilerde yayınlanan makaleler incelenerek 2016-2020 yılları arasını kapsayan "Web of Science (WOS)" veri tabanı kullanılarak yapılmıştır. Gelecek çalışmalarda Scopus, Elsevier, EBSCO, Emerald, Sciense Direct, Springer ve Wiley gibi farklı veri tabanlarından tersine lojistik alanına ait farklı yayın kriterleri (yayın türü ve dil kriteri gibi) seçilerek farklı dönemler için daha ayrıntılı çalışmalar hazırlanabilir. Ayrıca bu çalışmada bibliyometrik analiz Vosviewer programı ile gerçekleştirilmiştir. Gelecek çalışmalar için farklı görselleştirme programları (Sci2Tool, Citespace, R programlama vb.) kullanılarak daha farklı analizler ve görselleştirmeler yapılabilir.

\section{KAYNAKÇA (REFERENCES)}

Abdulrahman, M. D., Gunasekaran, A., \& Subramanian, N. (2014). Critical barriers in implementing reverse logistics in the Chinese manufacturing sectors. International Journal of Production Economics, 147, 460-471

Alkan, G. ve Yılmaz, B. ve Oğuz, S., (2020). Tersine Lojistik Alanındaki Yayınların Bibliyometrik Analiz Yöntemiyle Değerlendirilmesi, Atatürk Üniversitesi İktisadi ve İdari Bilimler Dergisi, 34(3), 711-729

Agrawal, S., Singh, R., \& Murtaza, Q. (2015). A literature review and perspectives in reverse logistics. Resources, Conservation and Recycling, 97, 7692.

Campos, E. A., Paula, I. C., Pagani, R. N., \& Guarnier, P. (2017). Reverse logistics for the end-of-life and end-of-use products in the pharmaceutical industry: A systematic literature review. Supply Chain Management: An International Journal, 22(4), 375-392

Carter, C.R. \& Ellram, L.M. (1998). Reverse logistics: a review of the literature and framework for future investigation. J.Busi. Logist., 1998, 19(1), 85102

Chaves, G.D.L.D., Balista, W.C. \& Comper, I.C. (2019). Logística Reversa: o Estado da Arte e Perspectivas Futuras, Eng Sanit Ambient, 24(4), 821831.

De Brito, M. P. (2003). Managing reverse logistics or reversing logistics management? ERIM PhD Series Research in Management, N. 35, Rotterdam: Erasmus University Rotterdam.

De Lima Simão, M.P., Barbosa, D.H., Barbosa, J.S.K., Leal, G.C.L., Galdamez, E.V.C. \& Cotrim, S.L. (2018). Emerging Trends and Collaborative Network Patterns on Reverse Logistics, Independent Journal of Management \& Production, 9(2), 321-339

Dhakal, M. (2018). Reverse logistics in micro businesses: An exploratory study. University of Plymouth, Doctor of thesis. 
Dirik, M. (2012). Tersine lojistik ve Karaman organize sanayi bölgesinde gıda sektöründe tersine lojistiğin değerlendirilmesine yönelik bir uygulama. Karaman: İşletme Anabilim Dalı Yüsek Lisans Tezi.

Fleischmann, K. (1997). Invasion of alien woody plants on the islands of Mahé and Silhouette, Seychelles. J. Veg. Sci., 8, 5-12.

Gallegos, G.M.C., Jiménez, M.A.V. \& Lara, B.N. (2019). Estudio Bibliométrico Comparativo Entre la Logística İnversa y la Logística Verde, Cimexus, 14(2), 153-169.

Govindan, K., \& Soleimani, H. (2016). A review of reverse logistics and closed-loop supply chains: A journal of cleaner production focus. Journal of Cleaner Production, 142(1), 371-384

Guarnieri, P., e Silva, L. C., \& Levino, N. A. (2016). Analysis of electronic waste reverse logistics decisions using strategic options development analysis methodology: a Brazilian case. Journal of Cleaner Production, 133, 1105-1117.

Hsu, C.-C., Tan, K.-C., \& Mohamad Zailani, S. H. (2016). Strategic orientations, sustainable supply chain initiatives, and reverse logistics: Empirical evidence from an emerging market. International Journal of Operations \& Production Management, 36(1), 86-110.

Kazemi, N., Modak, N. M., \& Govindan, K. (2019). A review of reverse logistics and closed loop supply chain management studies published in IJPR: A bibliometric and content analysis. International Journal of Production Research, 57(15-16), 4937-4960.

Kosacka-Olejnık, M., \& Werner-Lewandowska, K. (2020). Reverse logistics as a trend of XXI century-state of Art. Management Systems in Production Engineering, 28(1), 9-14

Lawani, S. M. (1981). Bibliometrics: its theoretical foundations, methods and applications. Libri, 31(1), 294-315.

Meade, L. \& Sarkis, J. (2002). A conceptual model for selecting and evaluating third-party reverse logistics providers. Supply Chain Management: an International Journal, 7 (5), 283-295

Rahman, S. (2003). Reverse logistics: An overview and a causal model. In D.A. Hensher \& K.J. Button (eds), Handbook of Transport and the Environment, Elsevier, Oxford

Rajagopal, P., Kaliani Sundram, V. P. \& Naidu, B. M. (2015). Future directions of reverse logistics in gaining competitive advantages: A review of literature. International Journal of Supply Chain Management, 4(1), 39-48.

Rogers, D. S., \& Tibben-Lembke, R. (2001). An examınation of reverse logistics practice. Journal Of Business Logistıcs, 22(2), $129-148$.

Tekin, M. (2015). Lojistik, 2.Baskı, Günay Ofset, Konya

Tekin, M. (2018). Akıllı bilgi çağı, 1. Baskı, Günay Ofset, Konya

Tekin, M. (2018). Akıllı işletme reçeteleri, 1. Baskı, Günay Ofset, Konya

Tekin, M., Öztürk, D. ve Bahar, İ. (2020). Ak1llı lojistik faaliyetlerinde blokzincir teknolojisi, Kent Akademisi, 13(3), 570-583

Öztürk, D. (2018). Tedarik zinciri yönetimi süreçlerini etkileyen faktörler. Uluslararası Sosyal ve Ekonomik Bilimler Dergisi, 6(1), 17-24.

Tibben-Lembke, R. S., \& Rogers, D. S. (2002). Differences between forward and reverse logistics in a retail environment. Supply Chain Management: An International Journal, 7(5), 271-282

Wang, J.-J., Chen, H., Rogers, D. S., Ellram, L. M., \& Grawe, S. J. (2017). A bibliometric analysis of reverse logistics research (1992-2015) and opportunities for future research. nternational Journal of Physical Distribution \& Logistics Management, 47(8), 666-687

Zikmund, W. G., \& Stanton, W. J. (1971). Recycling solid wastes: A channels-of-distribution problem. Journal of Marketing, 35(3), 34-39. 